\title{
Synthesis of oligo-RNAs with photocaged adenosine 2'-hydroxyls
}

\author{
Steven G Chaulk \& Andrew M MacMillan \\ Department of Biochemistry, University of Alberta Edmonton, Alberta, Canada T6G 2H7. Correspondence should be addressed to A.M.M. \\ (andrew.macmillan@ualberta.ca).
}

Published online 26 April 2007; doi:10.1038/nprot.2007.154

This protocol describes a general method for the preparation of RNAs in which the reactivity or hydrogen-bonding properties of the molecule are modified in a photoreversible fashion by use of a caging strategy. A single caged adenosine, modified at the $2^{\prime}$ position as a nitro-benzyl ether, can be incorporated into short RNAs by chemical synthesis or into long RNAs by a combination of chemical and enzymatic synthesis. The modified RNAs can be uncaged by photolysis under a variety of conditions including the use of a laser or xenon lamp, and the course of this uncaging reaction may be readily followed by HPLC or thin-layer chromatography.

\section{INTRODUCTION}

RNA molecules, in addition to being carriers of genetic information, play key roles in the regulation of transcription and translation and form the catalytic core of both the spliceosome and ribosome. The study of many RNA systems is complicated by the dynamic nature of RNA secondary and tertiary structures, the transient nature of RNA - RNA or RNA - protein complexes, and in some cases the chemical reactivity of the RNA itself.

One useful method to study discrete RNA (and DNA) structures has been to limit available conformations through site-specific intrastrand crosslinking ${ }^{1}$. An alternative approach, widely used in the study of biomolecular recognition or reactivity, is the "caging" of the molecule of interest whether it be a substrate, cofactor or enzyme $^{2}$. Classically, caged molecules are chemically modified such that they become activated upon photolysis. In the context of an RNA molecule, a caging approach might be used to block either chemical reactivity of the RNA or formation of secondary or tertiary structure (Fig. 1). The caged RNA system can be studied both before and after photolysis, thus permitting characterization of the two states and the transition between them.

The first application of the caging approach to studies of nucleic acid structure and function involved blocking the chemical reactivity associated with an RNA functionality, the $2^{\prime}$-hydroxyl group ${ }^{3-5}$, as specific RNA 2'-hydroxyls act as nucleophiles in a number of biologically important transesterifications ${ }^{6-11}$. In addition, interactions with 2'-hydroxyl groups are critical in the formation of higher order RNA structures as well as protein - RNA complexes.

Caging of a single 2 -hydroxyl in a short synthetic oligonucleotide blocks the cleavage reaction catalyzed by the hammerhead ribozyme ${ }^{6}$; cleavage is initiated by photolysis of the ribozyme - substrate complex ${ }^{3}$. This approach has also been extended to the caging of the branch adenosine ${ }^{11}$ in a fulllength precursor mRNA (pre-mRNA) for studies of RNA processing by the mamma- lian spliceosome $e^{4,5}$. Caging effectively isolates spliceosome assembly from catalysis of the splicing transesterifications, permitting a closer examination of the mechanisms of each. Thus, it has been established that ATP hydrolysis, while required for splicing, is not directly coupled to the first chemical step and also that phosphatase activities implicated in promoting both steps of splicing occur before the first chemical step ${ }^{4,5}$.

Subsequent to our initial report ${ }^{3}$, the site-specific caging of nucleic acids has been widely applied to regulate a variety of activities or processes including transcription, aptamer and DNAzyme activity, DNA replication and the formation of higher order RNA structures ${ }^{12-19}$. These experiments have involved either direct modification of pyrimidine or purine functionalities or of groups appended to them. Nonspecific caging of the phosphodiester backbone has been used to regulate gene expression in zebrafish embryos and to modulate siRNA activity in HeLa cells ${ }^{20,21}$. a
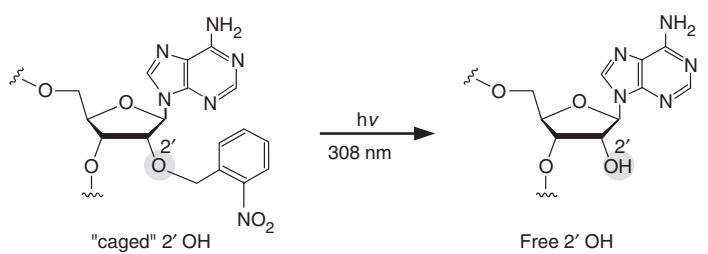

b
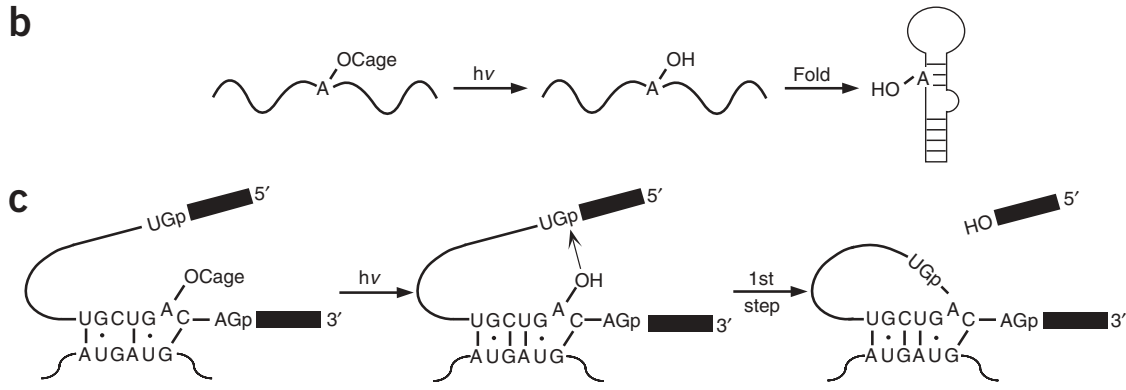

Figure 1 | Caged 2'-adenosines as tools for the study of RNA structure and function. (a) Caging of the 2'-hydroxyl of adenosine within RNA with an o-nitrobenzyl group that can be removed by photolysis; (b) caging the 2'-hydroxyl as a method of blocking structure formation for the examination of RNA folding pathways; (c) caging the 2'-hydroxyl as a method of blocking reactivity for the examination of reactions involving RNA such as pre-mRNA splicing. 
Our approach to caging the 2'-hydroxyl functionality relies on earlier work in which the development of methods for the automated synthesis of RNA molecules necessitated strategies for protection of the reactive 2 '-hydroxyl functionality. A variety of solutions to this problem have been explored including the use of the photo-labile $o$ nitrobenzyl moiety as a protecting group for the 2'-hydroxyl of the four RNA nucleosides $^{22-24}$. The synthesis of a caged adenosine phosphoramidite is straightforward (Fig. 2) and is especially facilitated by the fact that the desired 2'-modified adenosine nucleoside can be precipitated from the reaction solution. The caged adenosine is efficiently incorporated by standard automated synthesis into short synthetic oligomers that can then be purified by a combination of gel electrophoresis and HPLC (Fig. 3). The presence of the modified nucleotide is readily confirmed by enzymatic digestion and HPLC analysis (Fig. 4). This analysis also establishes that uncaging of the RNA proceeds with minimal if any damage to the nucleic acid.

This protocol describes the synthesis and characterization of a short RNA sequence in which a reactive $2^{\prime}$-hydroxyl is masked in a hammerhead ribozyme substrate (Steps 16-23). Further to this, a single caged nucleotide can be incorporated into a long RNA by
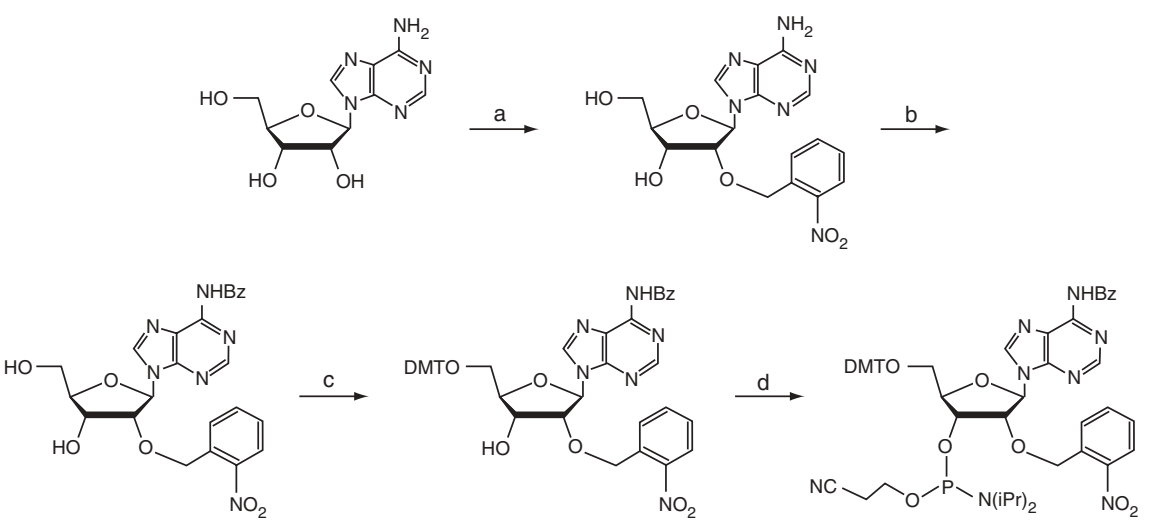

Figure 2 | Synthesis of 2'-caged adenosine phosphoramidite. a: o-nitro- $\mathrm{BnBr}, \mathrm{NaH}, \mathrm{DMF}$; b: trimethylsilylchloride, benzoyl chloride, pyr; c: DMTCl, DMAP, pyr; d: cyanoethyldiisopropylaminochlorophosphite, $i \operatorname{Pr}_{2} \mathrm{EtN}, \mathrm{THF}$.

\section{MATERIALS}

\section{REAGENTS}

- Solvents for organic synthesis are dried by conventional means or may be purchased commercially (Aldrich; Sure/Seal)

- Anhydrous pyridine (Aldrich, cat. no. 270970-100ML)

- Anhydrous dimethylformamide (DMF; Aldrich, cat. no. 227056-100ML)

- Anhydrous THF (Aldrich, cat. no. 401757-100ML)

- Flash silica gel 40-63 $\mu \mathrm{m}$ (Silicycle, cat. no. R10030B)

- TLC plates: silica gel 60 F254 $2.5 \times 7.5$ cm (EM Merck, cat. no. EM-15327-1)

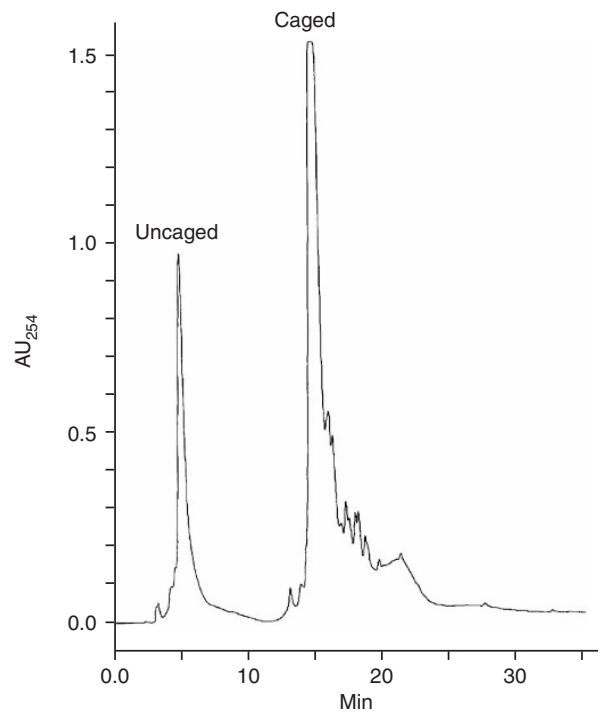

Figure 3 | HPLC purification of caged hammerhead substrate RNA. Following automated synthesis, deprotection and initial gel purification, uncaged RNA is separated from caged material by reverse-phase HPLC (elution times of $\sim 5$ and $\sim 15 \mathrm{~min}$, respectively, under the conditions of this experiment; see text). joining a synthetic oligomer containing the caged residue (prepared as in Steps 16-23) to T7 RNA polymerase transcripts using the Moore-Sharp ligation protocol (Fig. 5) (see refs. 25,26) This protocol describes the synthesis and characterization of one such RNA: a model human pre-mRNA splicing substrate (Steps 24-30).

The 2'-caged RNA is activated by photolysis using either a laser or a powerful lamp (depending on the application: see below), and the course of photolysis is readily monitored either by HPLC or thin-layer chromatography (TLC) analyses of enzymatic digests of the oligonucleotide (Figs. 3 and 4 ).
- Adenosine (Aldrich, cat. no. 14,659-5)

- Sodium hydride (Aldrich, cat. no. 45,291-2)

-2-Nitrobenzylbromide (Aldrich, cat. no. 10,779-4)

- Chlorotrimethylsilane (Aldrich, cat. no. C7,285-4)

- Benzoylchloride (Aldrich, cat. no. 25,995-0)

- Dimethylaminopyridine (DMAP; Aldrich, cat. no. 52,280-5)

-4,4'-Dimethoxytrityl chloride (DMTCl; Aldrich, cat. no. 10,001-3)

- $N, N$-Diisopropylethylamine (Aldrich, cat. no. D12,580-6)

-2-Cyanoethyl-N,N-diisopropylaminochlorophosphite (Aldrich, cat. no. 30,230-9)

- T7 RNA polymerase (Promega, cat. no. P 2075)

-2'-FPMP RNA phosphoramidites (Rasayan Inc.)

- 500 A FPMP-controlled pore glass resin (Rasayan Inc.)

- Methanolic ammonia (Aldrich, cat. no. 49,914-5)

- Calf intestinal alkaline phosphatase (NEB, cat. no. M0290S)

- Polynucleotide kinase (NEB, cat. no. M0201S)

- T4 DNA ligase (cat. no. P4557)

- Snake venom phosphodiesterase (AmershamBiosciences, cat. no. E202404)

- RNase A (Roche, cat. no. 109142)

- RNase T1 (Roche, cat. no. 109193)

- RNasin (Promega, cat. no. N2515)

- Cellulose PEI $4 \times 10 \mathrm{~cm}$ TLC plates (J.T. Baker, cat. no. 4474-04)

- $\left[\gamma_{-}{ }^{32} \mathrm{P}\right]$ ATP $\left(6,000 \mathrm{Ci} \mathrm{mmol}^{-1}, 5 \mathrm{mCi} \mathrm{ml}^{-1}\right.$; NEN, cat. no. NEG035C)

- C18 cartridge (Burdick \& Jackson, cat. no. 9200)

- Urea (Aldrich, cat. no. U270-9)

- Trizma acid (Tris-HCl; Sigma, cat. no. T6666)

- Trizma base (Tris base; Sigma, cat. no. T6791)

- Boric acid (Sigma, cat. no. B7660)

- EDTA (Sigma, cat. no. E1644)

- Sodium acetate (Sigma, cat. no. S7545)

- Phenol (Sigma, cat. no. P4557)

- Chloroform (Sigma, cat. no. C2432)

- Isoamyl alcohol (Sigma, cat. no. I9392)

- HEPES (Sigma, cat. no. H7523)

- PVP-40 (Sigma, cat. no. PVP-40) 
Figure 4 | HPLC nucleoside composition analysis of caged and photolyzed hammerhead substrate RNA. (a) Enzymatic digestion of caged hammerhead substrate RNA 5'-GGGUGUA*UGGUU-3' (A*: 2'-caged adenosine; G: guanosine; U: uridine); (b) enzymatic digestion of hammerhead substrate RNA containing a single $2^{\prime}$-caged adenosine residue following photolysis with an excimer laser (A: adenosine; G: guanosine; U: uridine).

- Bromophenol blue (Sigma, cat. no. B8026)

- Xylene cyanole (Sigma, cat. no. X4126)

\section{EQUIPMENT}

- Standard equipment for organic synthesis including glassware, Teflon stir bars, septa, syringes, needles, magnetic stir plate, flash column

$(4 \mathrm{~cm} \times 30 \mathrm{~cm})$ and a vacuum pump

- Plastic syringes are appropriate for transfers of all solvents except THF

- Pyrex tubes 4-5 cm long (cut NMR tubes are suitable) with cap

- Lambda Physik EMG 201 MSC excimer laser or water-jacketed 1,000 W

Oriel Xenon arc lamp

- Applied Biosystems 392 DNA/RNA Synthesizer

-UV spectrophotometer

- PAGE electrophoresis unit with power supply

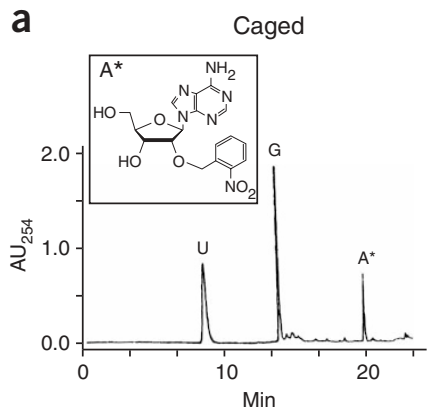

b Photolyzed

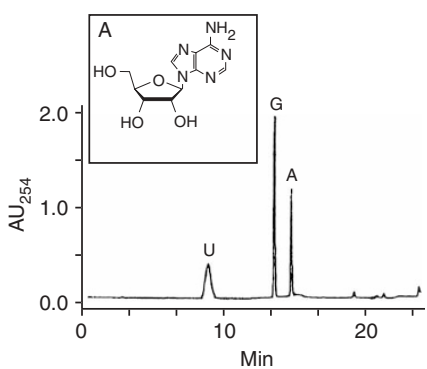

- Hand-held UV lamp

- Disposable filter columns (Fisher, cat. no. 11-387-50)

- Rotary evaporator (Buchi)

- Speed-vac concentrator (Savant)

- Waters HPLC

- Molecular Dynamics Storm 860 Phosphorimager

- Molecular Dynamics phosphor screen

\section{PROCEDURE}

\section{Synthesis of caged phosphoramidite}

\section{Synthesis of 2'-0-(2-nitrobenzyl)adenosine TIMING $\mathbf{1 2} \mathbf{~ h}$}

1) Dissolve adenosine $(1.0 \mathrm{~g}, 3.75 \mathrm{mmol}$; evaporated using a rotary evaporator three times from dry pyridine to remove water) in $34 \mathrm{ml}$ of hot dry DMF in a round-bottom flask containing a stir bar. To the stirring solution, add sodium hydride $(225 \mathrm{mg}, 60 \%(\mathrm{w} / \mathrm{v})$ in oil, washed three times with hexanes) as a suspension in $4 \mathrm{ml}$ of dry DMF using a $5 \mathrm{ml}$ syringe. Stir the resulting solution at $0{ }^{\circ} \mathrm{C}$ for 45 min under nitrogen.

I CAUTION Sodium hydride is highly flammable and reacts violently with water.

2| Add $1.21 \mathrm{~g}(5.6 \mathrm{mmol})$ of 2-nitrobenzylbromide (o-nitro- $\mathrm{BnBr})$ in $2 \mathrm{ml}$ of dry DMF using a syringe. Stir the reaction mixture at room temperature $\left(22{ }^{\circ} \mathrm{C}\right)$ under nitrogen for $5 \mathrm{~h}$.

I CAUTION 2-nitrobenzylbromide is a lachrymator.

3| Pour the reaction into $375 \mathrm{ml}$ of ice-cold water and stir the resulting mixture at room temperature.

PAUSE POINT The reaction thus quenched may be left stirring overnight.

a

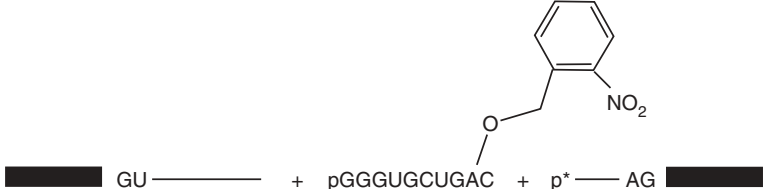

(3)

(2)

(1)

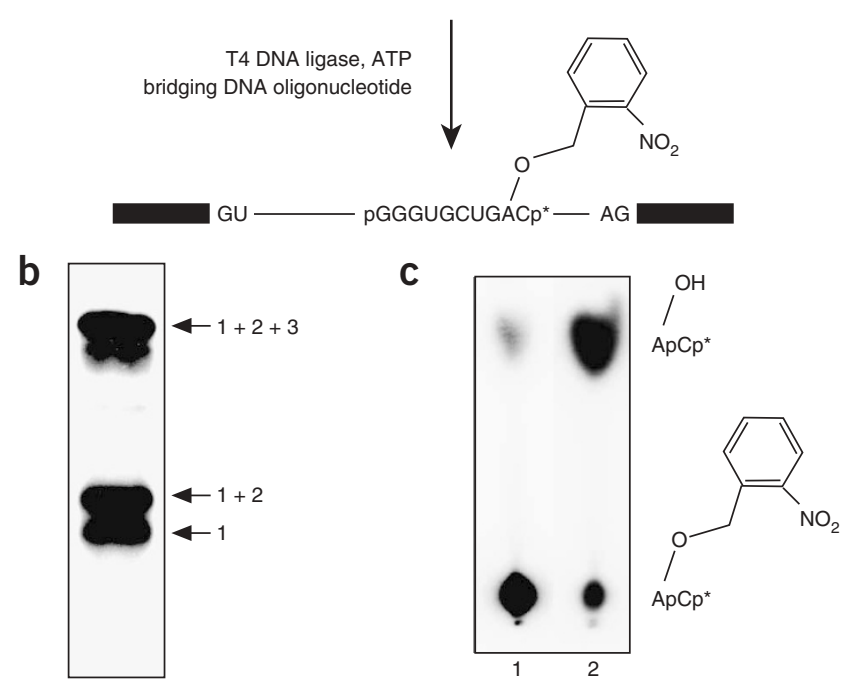

4 Collect the resulting yellow precipitate by vacuum filtration and dry in vacuo. The yield is assumed to be quantitative for the next step in the preparation.

$\triangle$ CRITICAL STEP Although the caged nucleoside is relatively stable in ambient light, at this stage and beyond, during prolonged reaction periods, the compound can be protected by wrapping glassware in an aluminum foil.

\section{Synthesis of 2'-0-(2-nitrobenzyl)- $N^{6}$-benzoyladenosine TIMING 12 h}

5| Add $3.8 \mathrm{ml}(30 \mathrm{mmol})$ of trimethylsilylchloride via syringe to a suspension of 2'-0-(2-nitrobenzyl)adenosine (1.5 g, $3.73 \mathrm{mmol}$ ) in $20 \mathrm{ml}$ dry pyridine under nitrogen. Stir the mixture for $30 \mathrm{~min}$ at room temperature.

Figure 5 | Synthesis of pre-mRNAs containing a caged 2' hydroxyl at the branch position. (a) Schematic of ligation: a synthetic oligomer containing a single modified adenosine residue (2: $5^{\prime}-\mathrm{GGGUGCUGA}{ }^{*} \mathrm{C}-3^{\prime}$; nucleotides 146-156) was ligated to T7 RNA polymerase trancsripts (1: nucleotides 157-234; 3: nucleotides 1-145) to yield full-length (234 nucleotide) caged PIP85.B pre-mRNA ${ }^{26}$ containing a single ${ }^{32} \mathrm{P}$ radiolabel $\left(\mathrm{p}^{*}\right)$; (b) denaturing PAGE purification of ligation (1: $3^{\prime}$ transcript; $1+2$ : ligation of caged synthetic oligomer to $3^{\prime}$ transcript; $1+2+3$ : full-length pre-mRNA; (c) TLC analysis of photolysis of caged pre-mRNA. Lane 1: unphotolyzed caged pre-mRNA digested with RNase A and RNase T1; lane 2: photolyzed uncaged pre-mRNA digested with RNase A and RNase T1. 
6| Add $2.4 \mathrm{ml}(20.6 \mathrm{mmol})$ of benzoyl chloride using a syringe and stir the reaction for another $2.5 \mathrm{~h}$.

7| Cool the resulting mixture to $0^{\circ} \mathrm{C}$ in an ice/water bath. Add $4 \mathrm{ml}$ of water and stir the reaction for $5 \mathrm{~min}$.

8| Add aqueous ammonia $(33 \%(\mathrm{w} / \mathrm{v}), 8 \mathrm{ml})$ and continue stirring for an additional $30 \mathrm{~min}$.

9| Concentrate the mixture in vacuo using a rotary evaporator and purify the product by silica gel flash chromatography using $5 \%(\mathrm{v} / \mathrm{v})$ methanol/methylene chloride as eluant $\left(R_{\mathrm{f}}=0.3\right)$ to yield $647 \mathrm{mg}$ of $2^{\prime}-0$-(2-nitrobenzoyl)- $N^{6}$-benzoyladenosine (43\% from adenosine).

$\triangle$ CRITICAL STEP This chromatographic separation requires a "dry load" of the reaction product: add 5-6 ml of silica gel to the concentrating reaction mixture (Step 9) and pour the dried silica/reaction product mixture directly on top of the packed silica flash column. Pour the eluant directly on the dry powder and run the column normally.

\section{Synthesis of $5^{\prime}-0-\left(4,4^{\prime}\right.$-dimethoxytrityl)-2'-0-(2-nitrobenzyl)- $N^{6}$-benzoyl adenosine TIMING $12 \mathrm{~h}$}

10| Dissolve $455 \mathrm{mg}(1.13 \mathrm{mmol})$ of $2^{\prime}-0$-(2-nitrobenzyl)- $N^{6}$-benzoyladenosine (evaporated three times from dry pyridine using a rotary evaporator), $6 \mathrm{mg}(0.05 \mathrm{~mol} \%)$ of DMAP and $355 \mathrm{mg}(1.1 \mathrm{mmol})$ of DMTCl in $2 \mathrm{ml}$ of dry pyridine. Stir the reaction mixture at room temperature for $5 \mathrm{~h}$ under nitrogen.

11 Concentrate the resulting mixture in vacuo and purify the product by silica gel flash chromatography using ethyl acetate as eluant $\left(R_{\mathrm{f}}=0.75\right)$ to yield $562 \mathrm{mg}(74 \%)$ of $5^{\prime}-0$-(4,4'dimethoxytrityl)-2'-0-(2-nitrobenzyl)- $N^{6}$-benzoyladenosine. Note that trityl-containing compounds can easily be visualized on a TLC plate, at this and later stages of the synthesis, by using a Pasteur pipette to puff vapor from concentrated $\mathrm{HCl}$ over the plate: trityl-containing compounds turn orange.

$\triangle$ CRITICAL STEP Because of the acid sensitivity of the trityl-containing compound, it is advisable, at this and the next stage of the synthesis, to wash the silica gel with $0.5 \%(\mathrm{v} / \mathrm{v})$ triethylamine in the elution solvent before running the flash chromatography column. Similarly, a small amount of triethylamine $(1 \mu \mathrm{l})$ should be added to the $\mathrm{CDCl}_{3} \mathrm{NMR}$ solvent before dissolving the sample for analysis.

\section{Synthesis of $5^{\prime}-0-\left(4,4^{\prime}\right.$-dimethoxytrityl)-2'-O-(2-nitrobenzyl)- $N^{6}$-benzoyladenosine $3^{\prime}-0$-(2-cyanoethyl- $N, N$ - diisopropylamino) phosphoramidite TIMING $12 \mathrm{~h}$}

12| Place a three-neck round-bottom flask under a positive pressure of nitrogen, flame-dry it, and then allow it to cool down to room temperature under nitrogen.

13| Dissolve $520 \mathrm{mg}$ (0.6 mmol) 5'-0-(4,4'-dimethoxytrityl)-2'-0-(2-nitrobenzyl)- $N^{6}$-benzoyl-adenosine in dry distilled THF $(3 \mathrm{ml})$ under nitrogen in the flame-dried flask.

14| Add $0.71 \mathrm{ml}$ (4 mmol) of diisopropylethylamine and $0.29 \mathrm{ml}(1.3 \mathrm{mmol})$ of 2-cyanoethyl- $\mathrm{N}, \mathrm{N}$-diisopropylaminochlorophosphite $(1.3 \mathrm{mmol})$ to the reaction using a syringe or by pipetman and allow the reaction to proceed for $6 \mathrm{~h}$ under nitrogen. Note that because the phosphite is very viscous, it is easiest to add to the reaction using a pipetman.

15 Pour the resulting mixture into $200 \mathrm{ml}$ of ethyl acetate and wash the resulting solution three times with $5 \%(w / v)$ sodium bicarbonate (100 ml per wash) in a separatory funnel. Dry the organic layer over $10 \mathrm{~g}$ of anhydrous magnesium sulfate.

Concentrate in vacuo using a rotary evaporator, and purify the residue by silica gel flash chromatography using $80 \%(\mathrm{v} / \mathrm{v})$ ethyl acetate/hexanes as eluant ( $R_{\mathrm{f}}=0.5-0.6$, both diastereomers) to yield $622 \mathrm{mg}(92 \%)$ of $5^{\prime}-0-\left(4,4^{\prime}\right.$-dimethoxytrityl)$2^{\prime}-0$-(2-nitrobenzyl)- $N^{6}$-benzoyladenosine-3'-O-(2cyanoethyl- $N, N$-diisopropylamino) phosphoramidite.

\section{Synthesis of a caged hammerhead ribozyme substrate $\bigcirc$ TIMING 1 week}

16| Synthesize 5'GGGUGUA*UGGUU-3' ( $A^{*}$ represents 2'-caged adenosine) using 2'-0-(2-nitrobenzyl) adenosine phosphoramidite and $2^{\prime}$-Fpmp phosphoramidites on a $1 \mu \mathrm{mol}$ scale using a DNA/RNA synthesizer. Use the standard RNA synthesis cycle with coupling times of $15 \mathrm{~min}$ for regular amidites and $30 \mathrm{~min}$ for the caged amidite.

$\triangle$ CRITICAL STEP Acid-labile Fpmp phosphoramidites are used in this synthesis rather than silyl-modified $t$-butyldimethylsilyl (TBDMS) or bis(acetoxyethoxy)methyl (ACE) phosphoramidites (which are deprotected with fluoride) because of the fluoride sensitivity of the nitrobenzyl ether functionality. Test reactions showed that $\sim 20 \%$ of the nitrobenzyl ether is removed upon treatment with fluoride under conditions used in deprotecting TBDMS-modified RNAs; thus, it is theoretically possible to use TBDMS chemistry in this protocol albeit with significantly lowered yields of caged RNA.

17| Cleave RNA from the resin and deprotect it by treatment with saturated ammonia/methanol $(1 \mathrm{ml})$ in screw-cap tubes at $55^{\circ} \mathrm{C}$. Spin the reaction mixture to separate the resin from ammonia/methanol. Recover the supernatant and lyophilize to dryness using a speed-vac concentrator.

PAUSE POINT Incubate the lyophilized reaction mixture at $55{ }^{\circ} \mathrm{C}$ for $20 \mathrm{~h}$.

18| Remove the 2'-Fpmp groups by treatment with $500 \mu \mathrm{l} \mathrm{NaOAc} \mathrm{(pH} \mathrm{3.25).}$ 
PAUSE POINT Incubate the reaction mixture for $40 \mathrm{~h}$ at room temperature.

$\triangle$ CRITICAL STEP The deprotected RNA is susceptible to degradation by ribonucleases, and standard precautions used when working with RNA should be observed.

19| Neutralize the mixture with $500 \mu \mathrm{l}$ Tris buffer (3.15 M, pH 9), precipitate the RNA with three volumes of ethanol by incubation for 20 min on dry ice and evaporate the product to dryness using a speed-vac concentrator.

20| Resuspend the crude product in gel loading buffer ( $8 \mathrm{M}$ urea, $1 \times$ TBE (90 mM Tris-borate, $2 \mathrm{mM} \mathrm{EDTA),} 1 \mathrm{mM}$ EDTA urea, $0.1 \% \mathrm{w} / \mathrm{v}$ each of bromophenol blue and xylene cyanole) and purify it by denaturing $20 \%(\mathrm{w} / \mathrm{v})(19: 1)$ PAGE $(18 \times 20 \mathrm{~cm}$, and $3 \mathrm{~mm}$ thick using a comb with one well; see http://genetics.mgh.harvard.edu/szostakweb/resources/Public\%20Protocols/ denaturepage/index.html). The caged RNA is located/visualized by UV shadowing. The band is excised, crushed with a glass rod and extracted with $10 \mathrm{ml}$ of $0.3 \mathrm{M} \mathrm{NaOAc}$ containing $500 \mu \mathrm{l}$ phenol/chloroform/isoamylalcohol (25:24:1) on an orbital shaker for $8 \mathrm{~h}$ at $4^{\circ} \mathrm{C}$.

PAUSE POINT The extraction can be performed overnight.

$\triangle$ CRITICAL STEP The caged RNA is visualized by UV shadowing with a hand-held $254 \mathrm{~nm}$ UV lamp. To prevent photolysis of the caged RNA with the lamp, the gel is covered with cardboard leaving only the outside edges and a portion in the middle of the gel visible. Only the portions of gel protected from exposure to UV light are excised.

21 The acrylamide is removed by spinning the extraction solution through a filter column $\left(3,000\right.$ r.p.m., $\left.4{ }^{\circ} \mathrm{C}, 10 \mathrm{~min}\right)$ and then the supernatant is extracted with chloroform/isoamyl alcohol (24:1) and precipitated with three volumes of ethanol (dry ice, $20 \mathrm{~min}$ ).

\section{HPLC purification of caged RNA $\bigcirc$ TIMING $8 \mathbf{h}$}

22 The recovered RNA consists of an $\sim 85: 15$ mixture of caged and uncaged RNA. Resuspend the mixture in $1 \mathrm{ml}$ of water and purify by $\mathrm{C}-18$ reverse-phase HPLC to yield pure caged RNA (elution time: $\sim 15$ min; gradient elution from 9:1 0.05 M triethylammonium acetate/acetonitrile to 7:3 $0.05 \mathrm{M}$ triethylammonium acetate/acetonitrile over $25 \mathrm{~min} ; 1 \mathrm{ml} \mathrm{min}^{-1}$ flow rate using an $85 \mathrm{ml}$ Waters C18 column). The yield of caged RNA is $20 \%$ (200 nmol) as determined by UV absorption at $260 \mathrm{~nm}$ (a molar extinction coefficient of $124,100 \mathrm{M}^{-1}$ for the caged RNA, including a value of $3,700 \mathrm{M}^{-1}$ for the nitrobenzyl group, is used in this calculation $)^{27}$.

$\triangle$ CRITICAL STEP Because exposure to UV light during the HPLC run results in partial uncaging of the sample, an analytical run is performed to obtain the elution time of the RNA and the subsequent preparative run is performed with the detector off. RNA can be detected in fractions collected around the expected elution volume by analytical UV spectroscopy at $260 \mathrm{~nm}$.

23| Ethanol-precipitate collected RNA, resuspend it in $100 \mu \mathrm{LTE}(10 \mathrm{mM}$ Tris pH 7, $0.1 \mathrm{mM} \mathrm{EDTA})$ and store at $-78{ }^{\circ} \mathrm{C}$ to minimize degradation. RNA is stable for at least 6 months under these conditions.

\section{Synthesis of a full-length caged pre-mRNA: branch region oligonucleotide synthesis $\bigcirc$ TIMING 10 days total}

24| An oligonucleotide representing the branch region of the PIP85B pre-mRNA ${ }^{28}, 5^{\prime}-G G G U G C U G A^{*} C-3^{\prime}$ ( $A^{*}$ represents $2^{\prime}$-caged adenosine) is synthesized, deprotected and purified as described above for the hammerhead substrate (Steps 16-23) giving an $\sim 20 \%$ (200 nmol) yield of caged oligonucleotide as determined by UV absorption at $260 \mathrm{~nm}$ (a molar extinction coefficient of $124,100 \mathrm{M}^{-1}$ for the caged RNA, including a value of 3,700 $\mathrm{M}^{-1}$ for the nitrobenzyl group, is used in this calculation) ${ }^{27}$.

25| Phosphorylate the caged oligonucleotide at the $5^{\prime}$ position: incubate for $10 \mathrm{~min}$ at $37^{\circ} \mathrm{C}$ in a $40 \mu \mathrm{l}$ reaction containing 300 pmol RNA, $70 \mathrm{mM}$ Tris pH 7.6, $10 \mathrm{mM} \mathrm{MgCl}$, 5 mM DTT, $1 \mathrm{mM}$ ATP and $4 \mathrm{U}$ T4 polynucleotide kinase.

26| Add $360 \mu \mathrm{l}$ of $0.3 \mathrm{M} \mathrm{NaOAc}$ to the reaction, extract the reaction mixture with phenol/chloroform/isoamyl alcohol and ethanol-precipitate the RNA (see Step 21).

\section{Synthesis of a full-length caged pre-mRNA}

27| PIP85.B is a 234-nucleotide optimized pre-mRNA that splices efficiently in HeLa nuclear extracts: 5'-GGGCGAAUUCGAGCUC ACUCUCUUCCGCAUCGCUGUCUGCGAGGUACCCUACCAG $\downarrow$ GUGAGUAUGGAUCCCUCUAAAAGCGGGCAUGACUUCUAGAGUAGUCCAGGGUU UCCGAGGGUUUCCGUCGACGAUGUCAGCUCGUCUCGAGGGUGCUGACUGGCUUCUUCUCUCUUUUUCCCUCAG $\downarrow$ GUCCUACACAA CAUACUGCAGGACAAACUCUUCGCGGUCUCUGCAUGCAAGCU-3' (splice sites indicated with arrows) ${ }^{28}$. Site-specific modifications can be introduced into this RNA by ligation of short synthetic oligomers containing the desired modification to the appropriate upstream and downstream T7 transcription products using a bridging DNA "splint"25. T7 transcriptions are performed under standard conditions in a $400 \mu \mathrm{l}$ reaction volume: $80 \mathrm{mM}$ Tris, $\mathrm{pH}$ 7.9, $12 \mathrm{mM} \mathrm{MgCl}, 4 \mathrm{mM}$ spermidine, $20 \mathrm{mM} \mathrm{NaCl}, 10 \mathrm{mM}$ DTT, $500 \mu \mathrm{M}$ each NTP, $0.25 \mu \mathrm{M}$ DNA template (generated by PCR from the appropriate plasmid to introduce a T7 promoter, $5^{\prime}$-TATAGT GAGTCGTATTA-3', at the $5^{\prime}$ end of the template) and $400 \mathrm{U}$ T7 RNA polymerase. 
28| Incubate for $3 \mathrm{~h}$ at $30^{\circ} \mathrm{C}$ the $5^{\prime}$-phosphorylated synthetic branch oligomer (nucleotides $146-156 ; 300$ pmol) with upstream PIP85.B RNA (nucleotides 1-145; 300 pmol) and 5' 32P-labeled downstream (nucleotides 157-234; 100 pmol) T7 RNA transcription products in the presence of a bridging DNA "splint" complementary to the RNAs (cDNA(169-136): 5'-GAGAGAAGAAGCC AGTCAGCACC CTCGAGACGAG-3'; $100 \mathrm{pmol}$ ) and $40 \mathrm{U}$ T4 DNA ligase (60 mM Tris, pH 7.8, $20 \mathrm{mM} \mathrm{MgCl}$, $36 \mathrm{U}$ ribonuclease inhibitor, $1.2 \mathrm{mM}$ ATP, 2.4\% (v/v) PVP-40, $5 \mathrm{mM}$ DTT).

29| Purify ligations directly by $15 \%$ (w/v) denaturing PAGE (see Step 20). The products are visualized by autoradiography (Fig. 5).

30| Extract the RNA from the gel slice (see Step 20), dissolve in a small volume of double-distilled water and store at $-78{ }^{\circ} \mathrm{C}$ (the sample is stable for at least 6 months under these conditions).

\section{Uncaging 2'-nitrobenzyl RNA}

31 Caged RNAs may be photolyzed using a variety of light sources including an excimer laser, as in option A, described as applied to the hammerhead ribozyme synthesized in Steps 16-23, or arc lamp, see option B, described as applied to the longer pre-mRNA synthesized in Steps 24-30. Because the deprotection times are similar, either option is appropriate for a generic caged RNA sequence. Note that the procedures for the analysis of the products from options A and B are specific to the RNA sequences used (hammerhead ribozyme and pre-mRNA). In particular, the analytical approach detailed in option $B$ relies on the presence of a ${ }^{32} \mathrm{P}$ radiolabel in both the caged and photolyzed pre-mRNA.

(A) Laser photolysis of caged hammerhead ribozyme substrate $\bigcirc$ TIMING $2 \mathbf{h}$

(i) In a cutoff pyrex NMR tube, prepare a solution containing caged hammerhead RNA ( $5 \mathrm{nmol}$ ), $50 \mathrm{mM}$ Tris, pH 7.5 and $10 \mathrm{mM} \mathrm{MgCl}$ in a $100 \mu$ volume.

(ii) Photolyze the solution in the NMR tube with 100 pulses $(308 \mathrm{~nm} ; 300 \mathrm{~mJ}$ per pulse; full beam: 1-3 cm) from a Lambda Physik EMG 201 MSC excimer laser.

$\triangle$ CRITICAL STEP Photolysis of the reaction results in heating of the reaction solution. Just before photolysis, cool the reaction mixture by placing the NMR tube on ice. Pyrex reaction vessels shield UV light of wavelengths shorter than $300 \mathrm{~nm}$, which can initiate unwanted crosslinking reactions.

(iii) Extract the reaction mixtures with phenol/chloroform/isoamyl alcohol and then ethanol-precipitate the RNA (see Step 19). Nucleoside composition analysis of caged and photolysis products $\bigcirc$ TIMING 1 day

(iv) Incubate a $5 \mathrm{nmol}(\sim 20 \mu \mathrm{g})$ sample of caged or photolyzed RNA in a $60 \mu \mathrm{l}$ reaction volume containing $0.2 \mathrm{mM} \mathrm{ZnCl}_{2}$, $16 \mathrm{mM} \mathrm{MgCl}, 250 \mathrm{mM}$ Tris, pH 6.0, $0.2 \mathrm{U}$ snake venom phosphodiesterase (Pharmacia) and $4 \mathrm{U}$ calf-intestinal alkaline phosphatase (NEB) at $37^{\circ} \mathrm{C}$ for $8 \mathrm{~h}$. The sample containing caged RNA should be protected from exposure to ambient light using aluminum foil.

PAUSE POINT The reaction may be left to proceed overnight.

(v) Following digestion, inject the sample onto a reverse-phase C-18 HPLC column (Waters) with a gradient elution from $0.05 \mathrm{M}$ triethylammonium acetate to $1: 10.1 \mathrm{M}$ triethylammonium acetate/acetonitrile $\left(16 \mathrm{~min} ; 1 \mathrm{ml} \mathrm{min}{ }^{-1}\right)$. Peaks corresponding to $\mathrm{U}, \mathrm{G}, \mathrm{A}$ and the modified nucleoside 2'-0-(2-nitrobenzyl)adenosine (there are no cytosines in the specific caged RNA substrate) are identified by coinjection of nucleoside standards with the chromatogram monitored at $254 \mathrm{~nm}$.

(B) Arc lamp photolysis of caged pre-mRNA substrate TIMING $2 \mathbf{h}$

(i) In a cutoff pyrex NMR tube, prepare a $10 \mu$ solution containing $50-100 \times 10^{3}$ c.p.m. of caged pre-mRNA in $60 \mathrm{mM} \mathrm{KCl}$ and $10 \mathrm{mM}$ HEPES, $\mathrm{pH}$ 8.0.

(ii) Cool the tube to $0{ }^{\circ} \mathrm{C}$ in an ice bath, remove and irradiate the sample at a distance of $1 \mathrm{~cm}$ with a 1,000 W Oriel Xenon arc lamp for $4 \mathrm{~s}$.

TLC analysis of caged pre-mRNA and photolysis products $\bigcirc$ TIMING $6 \mathrm{~h}$

(iii) The strategy for synthesis of the caged pre-mRNA (see Step 29; Fig. 5) results in a product with a single ${ }^{32}$ p label two nucleotides $3^{\prime}$ to the site of RNA modification with the caging group; thus, digestion of the RNA with RNase T1 and RNase A should yield $A^{2^{\prime} n b} p C p^{*}$ (for caged $R N A ; A^{2^{\prime} n b}$ corresponds to caged adenosine, $p^{*}$ corresponds to radiolabel) or $A p C p^{*}$ (for photolyzed RNA; $\mathrm{p}^{*}$ corresponds to radiolabel). Digest caged or photolyzed pre-mRNA (50-100 × $10^{3}$ c.p.m.) with $2 \mathrm{U}$ each of RNase $\mathrm{T} 1$ and RNase A ( $20 \mu \mathrm{l}$ reaction volume, $10 \mathrm{mM}$ Tris $\mathrm{pH} 7)$ for $2 \mathrm{~h}$ at $37^{\circ} \mathrm{C}$.

PAUSE POINT The digestion may be left overnight.

(iv) Concentrate the reaction to dryness using a speed-vac concentrator. Resuspend the residue in $4 \mu \mathrm{l}$ of water and load onto a cellulose PEI TLC plate $(4 \times 10 \mathrm{~cm})$ and elute for $1 \mathrm{~h}$ in 79:19:1 saturated $\left(\mathrm{NH}_{4}\right)_{2} \mathrm{SO}_{4} / 1 \mathrm{M} \mathrm{NH}_{4} \mathrm{OAc}$ /isopropanol.

The air-dried TLC plate is exposed to a Molecular Dynamics phosphor screen and then scanned using a Molecular Dynamics Storm 860 Phosphorimager.

\section{ANTICIPATED RESULTS}

\section{Phosphoramidite synthesis: typical yield}

The outlined synthesis of the caged phosphoramidite will yield enough caged phosphoramidite for approximately $21 \mu \mathrm{mol}$ couplings on a DNA/RNA synthesizer with a typical yield of $\sim 200 \mathrm{nmol}$ for a 10-nucleotide caged RNA. 


\section{Phosphoramidite synthesis: analytical data \\ 2'-0-(2-nitrobenzyl)- $N^{6}$-benzoyladenosine}

${ }^{1} \mathrm{H}$ NMR $\left(200 \mathrm{MHz}, \mathrm{CDCl}_{3}\right): \delta$ (p.p.m.) $8.72(\mathrm{~s}, 1 \mathrm{H}, \mathrm{H} 8), 8.12(\mathrm{~s}, 1 \mathrm{H}, \mathrm{H} 2), 8.04\left(\mathrm{~d}, 2 \mathrm{H}, \mathrm{NO}_{2}-\mathrm{ArH}\right), 7.85-7.82\left(\mathrm{~m}, 1 \mathrm{H}, \mathrm{NO}_{2}-\mathrm{ArH}^{2}\right.$, 7.61-7.28 (m, 6H, ArH), $6.00(\mathrm{~d}, 1 \mathrm{H}, 14 \mathrm{H}), 5.09-4.91(\mathrm{~m} \mathrm{2H}$, methylene), $4.71(\mathrm{~s}, 1 \mathrm{H}, 34 \mathrm{H}), 4.65(\mathrm{~d}, 1 \mathrm{H}, 24 \mathrm{H}), 4.21(\mathrm{~s}, 1 \mathrm{H}, 44 \mathrm{H})$, $3.87(\mathrm{dd}, 2 \mathrm{H}, 54 \mathrm{H})$.

The 2 ' position of the nitrobenzyl group was confirmed by NOED NMR data.

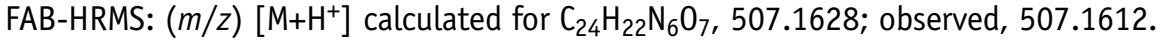

\section{$5^{\prime}-0$-(4,4'-dimethoxytrityl)-2'-0-(2-nitrobenzyl)- $N^{6}$-benzoyl adenosine}

${ }^{1} \mathrm{H}$ NMR (200 MHz, CDCl $)$ : $\delta$ (p.p.m.) $8.61(\mathrm{~s}, 1 \mathrm{H}, \mathrm{H} 8), 8.16(\mathrm{~s}, 1 \mathrm{H}, \mathrm{H} 2), 7.97\left(\mathrm{~d}, 2 \mathrm{H}, \mathrm{NO}_{2}-\mathrm{ArH}\right), 7.83\left(\mathrm{~d}, 1 \mathrm{H}, \mathrm{NO}_{2}-\mathrm{ArH}^{2}\right)$, 7.51-7.14 (m, 15H, ArH), $6.76(\mathrm{~m}, 4 \mathrm{H}, \mathrm{DMT}-\mathrm{ArH}), 6.18$ (d, 1H, 14H), 5.05 (dd, 2H, methylene), 4.27 (d, 1H, 44H), 3.71 (s, 6H, methoxy), 3.64-3.35 (m, 2H, 54H).

FAB-HRMS: $(\mathrm{m} / z)\left[\mathrm{M}+\mathrm{H}^{+}\right]$calculated for $\mathrm{C}_{45} \mathrm{H}_{40} \mathrm{~N}_{6} \mathrm{O}_{9}, 809.29347$; observed, 809.2913.

\section{$5^{\prime}-0$-(4,4'-dimethoxytrityl)-2'-0-(2-nitrobenzyl)- $N^{6}$-benzoyladenosine-3'-O-(2-cyanoethyl- $N, N$-diisopropylamino) phosphoramidite (caged phosphoramidite)}

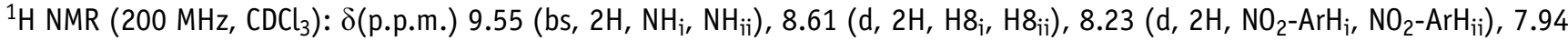
$\left(\mathrm{s}, 2 \mathrm{H}, \mathrm{H} 2_{i}, \mathrm{H}_{2 i i}\right), 7.75\left(\mathrm{~d}, 4 \mathrm{H}, \mathrm{NO}_{2}-\mathrm{ArH}_{\mathrm{i}}, \mathrm{NO}_{2} \mathrm{ArH}_{\mathrm{ii}}\right), 7.64\left(\mathrm{~d}, 2 \mathrm{H}, \mathrm{NO}_{2}-\mathrm{ArH}_{\mathrm{i}}, \mathrm{NO}_{2}-\mathrm{ArH}_{\mathrm{ii}}\right), 7.51-7.12\left(\mathrm{~m}, 30 \mathrm{H}, \mathrm{ArH}_{\mathrm{i}}, \mathrm{ArH}_{\mathrm{ii}}\right), 6.80-6.74$ $\left(\mathrm{m}, 8 \mathrm{H}\right.$, DMT-ArH $_{\mathrm{i}}$, DMT-ArH $\left._{\mathrm{ii}}\right), 6.26\left(\mathrm{~m}, 2 \mathrm{H}, 1^{\prime} \mathrm{H}_{\mathrm{i}}, 1^{\prime} \mathrm{H}_{\mathrm{ii}}\right), 5.26-4.90\left[\mathrm{~m}, 4 \mathrm{H}\right.$, methylene ${ }_{(\mathrm{i})}$, methylene $\left._{(\mathrm{ii})}\right], 4.69\left(\mathrm{~m}, 2 \mathrm{H}, 3^{\prime} \mathrm{H}_{\mathrm{i}}\right.$, $\left.3^{\prime} \mathrm{H}_{\mathrm{ii}}\right), 4.46\left(\mathrm{~m}, 2 \mathrm{H}, 2^{\prime} \mathrm{H}_{\mathrm{i}}, 2^{\prime} \mathrm{H}_{\mathrm{ii}}\right), 4.39\left(\mathrm{~m}, 2 \mathrm{H}, 4^{\prime} \mathrm{H}_{\mathrm{i}}, 4^{\prime} \mathrm{H}_{\mathrm{ii}}\right), 4.09-3.99\left(\mathrm{~m}, 4 \mathrm{H}, 5^{\prime} \mathrm{H}_{\mathrm{i}}, 5^{\prime} \mathrm{H}_{\mathrm{ii}}\right), 3.78-3.31$ [m, 8H, ethylene, cyanoethyl $_{(\mathrm{i})}$, cyanoethyl $\left._{(i i)}\right], 3.70\left[\mathrm{~d}, 12 \mathrm{H}\right.$, methoxy $\left.{ }_{(\mathrm{i})}, \operatorname{methoxy}_{(\mathrm{ii})}\right], 2.49-2.33\left[\mathrm{~m}, 4 \mathrm{H}\right.$, methine, $\left.\operatorname{Pr}_{(\mathrm{i})}, \operatorname{Pr}_{(\mathrm{ii})}\right], 1.29-0.91$ $\left[\mathrm{m}, 24 \mathrm{H}\right.$, methyl, $\left.i \operatorname{Pr}_{(\mathrm{i})}, i \mathrm{Pr}_{(\mathrm{ii})}\right]$.

${ }^{31}$ P NMR (300 MHz, $\mathrm{CDCl}_{3}$ ): $\delta, 151.27$ p.p.m., d, 150.94 p.p.m. (85\% (v/v) $\mathrm{H}_{3} \mathrm{PO}_{4}$ in $\mathrm{H}_{2} \mathrm{O}$ as external standard). FAB-HRMS: $(\mathrm{m} / \mathrm{z})\left[\mathrm{M}+\mathrm{H}^{+}\right]$calculated for $\mathrm{C}_{54} \mathrm{H}_{57} \mathrm{~N}_{8} \mathrm{O}_{10} \mathrm{P}, 1,009.4013$; found, $1,009.4019$.

COMPETING INTERESTS STATEMENT The authors declare that they have no competing financial interests.

Published online at http://www.natureprotocols.com Rights and permissions information is available online at http://npg.nature.com/ reprintsandpermissions

1. Allerson, C.R. \& Verdine, G.L. Synthesis and biochemical evaluation of RNA containing an intrahelical disulfide crosslink. Chem. Biol. 2, 667-675 (1995).

2. Mayer, G. \& Heckel, A. Biologically active molecules with a "light switch". Angew. Chem. Int. Ed. 45, 4900-4921 (2006).

3. Chaulk, S.G. \& MacMillan, A.M. Caged RNA: photo-control of a ribozyme reaction. Nucleic Acids Res. 26, 3173-3178 (1998).

4. Chaulk, S.G. \& MacMillan, A.M. Separation of spliceosome assembly from catalysis using caged pre-mRNA substrates. Angew. Chemie Int. Ed. 40, 2149-2152 (2001).

5. Chaulk, S.G., Kent, 0.A. \& MacMillan, A.M. Photo-control of RNA processing. in Dynamic Studies in Biology: Phototriggers, Photoswitches, and Caged Biomolecules (eds. Goeldner, M. \& Givens, R.) 495-513 (Wiley-VCH Weinham, Germany, 2005).

6. Uhlenbeck, 0.C. A small catalytic oligoribonucleotide. Nature 328, 596-600 (1987).

7. Branch, A.D. \& Robertson, H.D. Efficient trans cleavage and a common structural motif for the ribozymes of the human hepatitis delta agent. Proc. Natl. Acad. Sci. USA 88, 10163-10167 (1991).

8. Buzayan, J.M., Gerlach, W.L. \& Bruening, G. Nonenzymatic cleavage and ligation of RNAs complementary to a plant-virus satellite RNA. Nature 323, 349-353 (1986).

9. Guo, H.C. \& Collins, R.A. Efficient trans-cleavage of a stem-loop RNA substrate by a ribozyme derived from Neurospora VS RNA. EMBO J 14, 368-376 (1995).

10. Peebles, C.L. et al. A self-splicing RNA excises an intron lariat. Cell 44, 213-223 (1986).

11. Konarska, M.M. et al. Characterization of the branch site in lariat RNAs produced by splicing of messenger-RNA precursors. Nature 313, 552-557 (1985).

12. Kröck, L. \& Heckel, A. Photoinduced transcription by using temporarily mismatched caged oligonucleotides. Angew. Chem. Int. Ed. 44, 471-473 (2005).

13. Heckel, A. \& Mayer, G. Light regulation of aptamer activity: an anti-thrombin aptamer with caged thymidine nucleobases. J. Am. Chem. Soc. 127, 822-823 (2005).
14. Mayer, G. et al. Light-induced formation of G-quadruplex DNA secondary structures. ChemBioChem 6, 1966-1970 (2005).

15. Ting, R., Lermer, L. \& Perrin, D.M. Triggering DNAzymes with light: a photoactive C8 thioether-linked adenosine. J. Am. Chem. Soc. 126, 12720-12721 (2004).

16. Tang, X.J. et al. Photoregulation of DNA polymerase I (Klenow) with caged fluorescent oligodeoxynucleotides. Bioorg. Med. Chem. Lett. 15, 5303-5306 (2005).

17. Wenter, P. et al. Kinetics of photoinduced RNA refolding by real-time NMR spectroscopy. Angew. Chem. Int. Ed. 44, 2600-2603 (2005).

18. Höbartner, C. \& Silverman, S.K. Modulation of RNA tertiary folding by incorporation of caged nucleotides. Angew. Chem. Int. Ed. 44, 7305-7309 (2005).

19. Tang, X.J. \& Dmochowski, I.J. Phototriggering of caged fluorescent oligodeoxynucleotides. Org. Lett. 7, 279-282 (2005).

20. Monroe, W.T. et al. Targeting expression with light using caged DNA. J. Biol. Chem. 274, 20895-20900 (1999).

21. Shah, S., Rangarajan, S. \& Friedman, S.H. Light-activated RNA interference. Angew. Chem. Int. Ed. Engl. 44, 1328-1332 (2005).

22. Ohtsuka, E., Tanaka, S. \& Ikehara, M. Studies on transfer ribonucleic-acids and related compounds. 16 . Synthesis of ribooligonucleotides using a photosensitive orthonitrobenzyl protection for 2'-hydroxyl group. Chem. Pharm. Bull. 25, 949-959 (1977).

23. Bartholomew, D.G. \& Broom, A.D. One-step chemical synthesis of ribonucleosides bearing a photolabile ether protecting group. J. C. S. Chem. Commun. 2, 38 (1975).

24. Ohtsuka, E. et al. Studies on transfer-RNA and related compounds. 37. Synthesis and physical properties of 2'- or 3'-0-(ortho-nitrobenzyl) nucleosides - the use of orthonitrophenyldiazomethane as a synthetic reagent. Chem. Pharm. Bull. 29, 318-324 (1981).

25. Moore, M.J. \& Sharp, P.A. Site-specific modification of pre-mRNA: the 2'-hydroxyl groups at the splice sites. Science 256, 992-997 (1992).

26. MacMillan, A.M. et al. Dynamic association of proteins with the pre-mRNA branch region. Genes Dev. 8, 3008-3020 (1994).

27. Ohtauka, E., Tanaka, S. \& Ikehara, M. Studies on transfer ribonucleic acids and related compounds. (IX) Ribo-oligonucleotide synthesis using a photosensitive o-nitrobenzyl protection at the 2'-hydroxyl group. Nucleic Acids Res. 1, 1351-1357 (1974).

28. Query, C.C., Moore, M.J. \& Sharp, P.A. Branch nucleophile selection in pre-mRNA splicing: evidence for the bulged duplex model. Genes Dev. 8, 587-597 (1994). 